Conference Paper

\title{
The Existence of Same-Sex Marriage in the Perspective of Human Right and Legal in Indonesia
}

\author{
I. Made Suwitra ${ }^{1}$, I. Wayan Wesna Astara ${ }^{1}$, I. Ketut Kasta Arya Wijaya ${ }^{1}$, \\ I. Made Minggu Widyantara ${ }^{1}$, Putu Sawitri Nandari \\ ${ }^{1}$ Faculty of Law Universitas Warmadewa Denpasar, Bali, Indonesia \\ ${ }^{2}$ Faculty of Law Universitas Pendidikan Nasional Denpasar, Bali, Indonesia
}

Email address:

madesuwitra@yahoo.co.id (I. M. Suwitra)

\section{To cite this article:}

I. Made Suwitra, I. Wayan Wesna Astara, I. Ketut Kasta Arya Wijaya, I. Made Minggu Widyantara, Putu Sawitri Nandari. The Existence of Same-Sex Marriage in the Perspective of Human Right and Legal in Indonesia. Advances in Sciences and Humanities.

Vol. 5, No. 2, 2019, pp. 49-54. doi: 10.11648/j.ash.20190502.12

Received: January 16, 2019; Accepted: March 22, 2019; Published: April 18, 2019

\begin{abstract}
Marriage Problems in Indonesia before The issuance of Act No. 1 of 1974 concerning Marriage as a State law was regulated in the customary law of each customary law community. Regarding the terms and validity of the marriage submitted to their respective religious law. Therefore, whether such marriage is permitted or not is determined by the laws of each religion. After the issuance of Act No. 1 of 1974, same-sex marriage has not been regulated, but their existence as citizens is not differentiated from other citizens, such as the right to life, the right to work, the right to use the right on politic, the right on education, the right on economy. Therefore the research problem that needs to be studied is how the marriage is seen from the perspective of Human Rights and from the perspective of State Law? The research method used is in the form of normative legal research and empirical legal research with statute approaches, analytical approaches, case approaches, and legal anthropology approaches. Data is then analyzed using hermeneutic and qualitative techniques. Marriage in customary law and state law can only be done between men and women in Balinese customary law are known as purusa and predana, with the main goal of continuing a generation which according to Balinese customary law is called suputra. Marriage is having the aspect of religious, sociological, and juridical. While the tendency shows, same-sex marriage is done by falsifying documents of self-identity so that it is against the state law and customary law which include religious laws. Therefore, those who are only interested in the same sex must make gender choices as part of human rights when they are married to a single status as a male and the other party has the status of a woman who can be legally represented by various documents, as well as sociologically reflected as husband and wife and can be accepted in the community where they are resided.
\end{abstract}

Keywords: Customary Law, Human Right and Legal, Legalality of Marriage in, Same-Sex Marriage

\section{Background}

One of the most fundamental rights of human is the right to marry. The institution of marriage is a legalization for the humanity of different sex to conduct a relationship like husband and wife with the aim of obtaining offspring. In the view of religious law, the institution of marriage is a means for its people to purify and validate the biological relationship between a man and a woman as husband and wife.

In Indonesia, prior to the establishment of Act No. 1 of 1974 on Marriage, marriage problems from the Indonesian people become matters of customary law and religious law of the people concerned. This condition is very relevant to the theory of Reciptio in Complexu by Van den Berg which states, that as long as has not been proven otherwise, then the indigenous law is to follow his religion, then if embraced religion must also follow the religious laws faithfully. Or in other words, the customary law of society is the reception or acceptance of the whole religious law of the people concerned [1].

In Article 1 of Act Number 1 Year 1974 regarding Marriage is formulated that:

Marriage is a bond of birth and mind between a man and a 
woman as husband and wife with the aim of forming a happy and eternal family (household) based on the One Supreme Godhead.

This article clearly shows the meaning of the basic bond between man and woman as husband and wife is the law of religion and belief, that is reinforced through the provision of Article 2 Paragraph (1) of Law no. 1 of 1974 which formulates:

Marriage is legal if done according to their respective religions and beliefs.

So religious law is a tool to legalize marriage. Establishment of the recognition of religious law in marriage legislation indicates that Law No.1 of 1974 has a function as a social control, namely to establish and strengthen the religious norms of Indonesian society pluralism nationally within the framework of Republic of Indonesia (NKRI). It is relevant to what Roescoe Pound puts forward, that there are two functions of law, namely law as social control and law as social engineering [2]. In its development the function of law should be improved in order to play the role as an instrument to maintain and strengthen the integration of the nation in a multicultural society [3].

Marriage is one of the fundamental rights of human beings to be able to develop its generation, which is affirmed in the provisions of Article 10 of Law No. 39 of 1999 on Human Rights which formulates:

(1) Everyone has the right to form a family and continue the offspring through legitimate marriage.

(2) Legitimate marriages can only take place at the free will of the prospective husband and the future wife, in accordance with the provisions of the legislation.

The basic philosophy of the establishment of Act No.39 year 1999 is to recognize the implementation of the basic human rights which are owned by nature and its protection by the state when there is a violation. Humans as God's creatures bear the task of managing and maintaining the universe responsibly for the welfare of mankind, ensuring the existence of dignity and dignity of its own glory and harmony of its environment. In addition to human rights, human beings also have basic duties between humans against each other and the community as a whole in the life of society, nation, and state. Therefore, between rights and obligations is an inseparable value of antinomy, but it is in balance.

The right to form families to continue their offspring through marriage as one of the basic rights of human beings is often misrepresented by a group of people, especially gay and lesby groups in the struggle for their basic rights. According to them human rights are translated as "freedom of rights" according to individual taste and will and irrespective of obligation to comply with other norms. It means marriage is the right of everyone without any conditions, provided, when there is "love". So marriage between people of the same sex is considered to be a part of human rights that should not be prohibited. In reality, every region still considers that same-sex marriage is a forbidden act and is not justified by religious law. So the existence of similar marriages in Indonesia will be examined from the aspects of state law, customary law, and human rights law.

\section{Methods of Research}

This writing uses normative research methods, because it is considered there is duplication of norms in the development of community culture in global development. Normative legal research is matched by research using only secondary data [4]. This writing uses a staute approach, concept approach [5]. It also used analytic approach and case approach [6]. The data used are secondary data called legal materials, whether in the form of primary legal materials, such as the 1945 Constitution of Republic of Indonesia, Act no. 39 of 1999, Awig-Awig (traditional Law), and secondary law material in the form of reading material in the form of books and other scientific papers.

Secondary data in the form of legal materials is then analyzed by hermeneutical technique means searching for meaning and formulating it by giving interpretation of the text into objects to be interpreted, an understanding of a particular historical and sociological background to the problems that surround it, and in the context of space and time [6].

The hermeneutic paradigm in law science, which Jazim Hamidi called hermeneutic of law states that:

In relation to the hermeneutics of law as the philosophical teaching of its essence on the matter of understanding / understanding something, or an interpretation of the text. The word "texts" can mean: legal texts, legal events, legal facts, official documents of the country, ancient texts, holy scriptures, holy judgments of jurists (doctrines) In the frame of relevance between text, context, and contextualization [7]:

Earl Babbie mentions the development of hermeneutics as follows:

"Jurgen Habermas and others have adapted the process of hermeneutics, which originally referred to the interpretation of religius texts, to the understanding of social life. As used in the social sciensces, hermeneutics aim at understanding the process of understanding. Whereas the interpretativist seeks to discover how the subject interprets his or her experience of life, the hermeneuticst is more interested in the interpretivist's process of discovery"[8]. The meaning of hermeneutics in accordance to Habernas initially refers to the interpretation on holy bibles to the understanding on social life. In Social Science hermeneutics is used to direct to the process of understanding. Then to the interpretation to discover the meaning on their life experience, hermeneutics is more interested in the process of interpretation to a new findings")

The above analysis is also accompanied by case law analysis [9], meaning to look at the characteristics of each case to be sought legal meaning through hermeneutical methods in relation to each problem to be analyzed.

\section{Discussion}

\subsection{Same-Sex Marriage in the Perspective of State Law}

The said State Law is a legislation established by the 
competent institution, namely the Legislature (DPR) with the Executive (President) as defined in Article 20 of the 1945 Constitution of Republic of Indonesia. Human Rights is a set of rights attached to the nature and existence of human beings as The Creator of the Almighty God and His grace which must be respected, upheld and protected by the state, law, Government, and every person for the honor and protection of human dignity and prestige. Thus affirmed in Article 1 number 1 of Law no. No. 39 Year 1999 on Human Rights. One of human rights is the right to form a family through marriage in an attempt to legitimately continue its generation.

Naturally two humans of different sexes, a woman and a man, have the power to attract one another to live together. However, it should not be interpreted always in the context of intercourse, but can be recognized as a motivating factor to live together for the purpose of getting offspring or simply fulfilling lust [10]. This collective life is very important in society. The closest result is that by living together between these two humana they simply isolate themselves from other members of the community as new partners, and when their offspring become a separate family.

Marriage is conceived as a legitimate connection between a man and a woman for a long time [11]. In Article 26 Bergerlijk Wetboek (Book of Civil Law) ever applied in Indonesia, marriage is considered only as an act of civility, meaning that rules according to religion were not important as long as it was not regulated in a civil law relationship. So marriage was only viewed as a legal institution and was not dependent on the views of the future of a husband and wife. Therefore for the validity of a marriage is performed by a civil registry officer (Bergerlik Stand) after fulfilling the conditions prescribed by the Act.

Bergerlijk Wetboek does not formulate the concept of marriage, but Sholten gives marriage formulation as a legal relationship between a man and a woman to live together eternally, which is recognized by the country [12].

With the enactment of Law no. 1 of 1974 concerning Marriage, all regulations in the Burgerlijk Wetboek, Huwelijks Ordonantie Christen Indonesiaers: 1933-74, Regeling op de Gemeng de Huwelijken S. 1898-158, shall be declared null and void as provided for in this Law.:

In Article 1 of Act No. 1 Year 1974 mentioned:

Marriage is the inner bond between a man and a woman as a husband and wife with the aim of forming a happy, everlasting family or household based on the One Supreme Godhead.

How is the link between Act No. 1 of 1974 and Act no. 39 of 1999 in global development in observing the concept of "freedom of right" for every individual to do marriage, especially for potential couples who have sex (sex)? Historically there were some marriage rules that have been in effect before the enactment of Act No. 1 of 1974.

In Burgerlijk Wetboek determined, that to be able to make a marriage must meet the requirements, namely:

1. The two parties have reached the age set by the law, that is, for a man already 18 years of age, while for a woman is 15 years old;

2. There is no prohibition in the law for both parties, such as not being bound by marriage to another party, there is a close relationship of blood from both straight and upward;

3. For a woman who has been married within 300 days of her marriage;

4. For an underaged, there must be a consent from the parent or guardian;

5. There is a agreement of being free from both parties;

After the enactment of Act no. 1 Year 1974, then the parties who will marry must meet the following conditions:

1. Based on the agreement of both parties

2. For those who have not reached the age of 21 years, must get a permit from their parents. In such circumstances a permit may be granted by the guardian, one of the surviving parent, or the Court;

3. The man has reached the age of 19 (nineteen) years, and the woman has reached the age of 16 years. The deviation can be done by dispensation by the Court;

4. The parties have no blood relation in a straight line up or down, related to semenda, dairy relationships, relationships with aunts, nephews, and who have a religious relationship prohibited to mate;

5. Not being bound by marriage with others;

6. For divorced women, there is a waiting time to marriage again.

7. Not as a former husband or wife for a second marriage.

Observing the laws of marriage, and some doctrines, concepts and analytic approaches can be analyzed, that marriage on the one hand is one of the basic rights of man, meaning that each person is naturally entitled to build a household in order to sustain his descendants. In exercising this fundamental right, the parties are also free to determine their spouses normatively defined as "the parties' consent," meaning that no one can intervene in "agreement" as the fundamental right of every human being in determining his spouse. It must be understood, however, that the misguided interpretation of "consent" as freedom in the context of the basic right can be mistaken in thinking if it is not combined with its legal norms as the basic guidelines of society and state as a unified system.

Conceptually it has been formulated that marriage is a form of bonding as an agreement between "a man" and a woman "to form a family with the aim of continuing the family. Thus the essence of the meaning of the concept of formulation, that the institution of marriage becomes a tool (tool) for "men" and "women" to develop their families or their relatives through a biological relationship that can be justified juridically, philosophically, and sociologically.

In conducting marriage as freedom and basic human rights, the State establishes the juridical requirements in the Law of marriage to be guided by every state with the goal of creating social order and ensuring legal certainty, justice, and expediency.

The law by Van Kant is in charge of ensuring the legal certainty (rechtszekerheid) in human relationships. This means that the law guarantees the right to one party to the other. In addition there is no duplication between the rule of 
law which one with the rule of law other, and do not have other interpretations [13]. Legal certainty can be conceived as a legal instrument of a country that is able to guarantee the rights and obligations of every citizen [14]. On the other hand, Jan Michiel Otto revealed that there is little "real legal certainty" or legal certainty of juridic who in certain situations fulfills several indicators, namely:

1. There are clear legal rules (clear), consistent and accessible, published by or acknowledged because of (power) state;

2. The governmental authorities apply the rules of the law consistently and also subject to and obey them;

3. Most citizens principally adapt their behavior to those rules;

4. The judges (judges) who are independent and impartial take the law's rules consistently as they resolve the legal cruelty;

5. Concrete judicial decisions are implemented [15].

With the clarity of marriage arrangements in the state legislation both in Bergerlijk Wetboek and Act no. 1 of 1974, there is already a guarantee of legal certainty in relation to the meaning of freedom as a basic human right in carrying out its marriage, so that there is no violation of human rights that have been echoed by gay and lesbian in Indonesia and other countries. In addition, there is no reason to make interpretations other than to pay attention to the relationship between chapter one with the other as a whole harmony.

Currently it is recognized there are some countries that have legalized marriage between sexes, such as: Netherlands, Canada, Sweden, Belgium, and Spain that can be watched through Youtube accessed on 20 May 2017 for various reasons. This condition is not necessarily must be copied and paste by other countries, such as Indonesia which is always said Gay and Lesby because every country has a very different culture as the identity of the nation.

The Marriage Law in Indonesia in the perspective of justice can be declared to have fulfilled the requirements of justice, because it has guaranteed the freedom for everyone to form a family that has also been clearly defined the requirements. It is relevant to Aristotle's justice that states that justice is a virtue related to human relationships. [16] The word fair according to him contains more than one meaning. Fairness can mean according to law, and what is comparable, that is supposed. People who ignore the law are also unfair, because all things based on the law can be regarded as fair [16].

In the perspective of justice the term freedom to form the family as part of human rights must follow the norms of law that apply as part of the fundamental obligation with the aim of creating order and peace in the community. Legal norms only allow for different sex parties, between "a man and a woman" as husband and wife to form an eternal and happy family through marriage. And the essence of marriage is to continue the generation as a descendant, so that the concerned family is not extinct. Therefore, in the logic of the law, it is impossible for a hereditary to be born of a similar marriage, whether between a fellow man or a fellow woman. Which conditions can be expressed against nature's nature or deviant behavior.

In the perspective of Utilitarianism or Bentham Utilism which excites the benefit as the main purpose of law. Utilization is defined as happiness. So whether bad or fair is a law, depends on whether the law gives happiness to man or not. This happiness should be perceived by every individual. But if it is not possible (and certainly impossible), it is attempted that the happiness be blessed by as many individuals as possible in the society (the greatest happiness for the greatest number of people) [16]. So the benefits of a marriage are heredity, not sexual gratification. Therefore the formulation of the articles in Law no. 1 year 1974 systematically indicates that marriage can only be done by a man with a woman and is not a violation of human rights.

\subsection{Same-Sex Marriage in the Perspective of Customary Law}

At the conclusion of Seminar on Customary Law and National Law Development in Yogyakarta 15-17 January 1975 , it was formulated that customary law as the law of indigenous Indonesian nation not written in the form of legislation of Republic of Indonesia which here contains religious element [17].

Taking into account the formulation of customary law indicates that customary law is unwritten as a reception of the religious law of its people. As in Bali the customary law known as Awig-Awig is a reception of Hinduism, meaning Hindu customs and religion in Bali are different, but inseparable, because in every customary activity is accompanied by religious ceremonies. Conversely, in every religious activity enlivened and supported by custom.

Marriage in customary law is seen as a communal religious act. Similarly Bali sees marriage as a "holy" act so that to legalize it is done by religious law (Hindu). Concerning the concept, the terms and procedures are regulated in Awig-Awig of customary village. As in Article 68 Awig-Awig (traditional Law) Sidakarya customary village, Denpasar mentions:

(1) The implementation of the marriage which is considered proper / true in Sidakarya customary village is the bond of men and women on the basis of unity of soul and love the same love and based on tri ceremony of trials, that is carried out with religious ceremony, witnessed by banjar and family, and spirit of the ancestors.

(2) Based on free will

(3) Following the terms and procedures as stipulated in Act No. 1 year 1974

A similar formula is also found in Awig Awig Gelgel customary village Klungkung arranged in Article 25. So from the formulation of Awig-Awig of customary village it can be concluded that the marriage which is considered proper is if done by a man and a woman who is constituted by love and free will and not based on the will of parents' marriage and also not contradictory to Law No.1 of 1974. Therefore, awig-awig of customary village also does not justify and refuse same-sex marriage. 


\subsection{Case Analysis}

There are several interesting cases to analyze: First, marriage between Heniyati age 25 years, resident of Dukuh / Desa Pengkol, Kecamatan Karanggedhe, Boyolali with M Effendi Saputra 40 years old, turned out to be a woman with falsified identity as man, because Original Identity Card (KTP) of Effendi known named Suwarti. The case was handled by the police in Polres Boyolali.

Second, Marriage in Pekanbaru between D who uses false identity as a man married a woman in initial RE on April 7, 2016 ago. But RE does not know if the prospective husband was a woman. This is because his posture and voice are exactly the real guy. So on April 7 it was held a Kabul permit in KUA (The Office of Religion Affairs) Rengat. But recently the KUA (The Office of Religion Affairs) get news that the groom is a woman. The suspicion was added again because $\mathrm{D}$ did not want to give the latest photo to be paired with marriage book. Then after being traced the truth was right, that $\mathrm{D}$ was a woman. Finally the KUA (The Office of Religion Affairs) Rengat party canceled the marriage because it did not meet the Islamic Shari'a. In this case it is suspected that there are temporary officer on registration service office which help to fudge ID card and Family Card who are charged and currently has been determined as a suspect.

Mayor of Bandung Ridwan Kamil, had said not to question the lesbian, gay, bisexual, and transgender (LGBT) as long as it entered the private sphere or personal. But he will take firm steps if LGBT exists in the public sphere and campaigns. In the middle of LGBT rejection action in Bandung City Hall, Mashun Sofyan as coordinator of Youth and Youth Bandung Youth Alliance Action Reject LGBT criticize the statement. "The mayor should reject all LGBT activities, not just in private terms," said Mashun. According to him, the man who is familiarly called Emil is likely to carry freedom in the name of human rights (HAM). So LGBT activities are not at issue as long as it is done in secret. "He may be in the name of freedom of human rights, but LGBT is clearly against Islam, we want the mayor to reject LGBT with his activities," said Mashun.

He said LGBT has existed for a long time in Indonesia. But lately LGBT became rampant because of the parties who breathed freedom of human rights. "It means that LGBT and its activities do not stand alone, there are figures who support with the mode of freedom of human rights adopted from the West, it should be removed," said Mashun. The idea of freedom of human rights which has been echoed by some parties has made human actions become corrupt and far from religion, one of which encourages someone to become LGBT.

The existence of several cases of same-sex marriage in some areas in Indonesia can not be interpreted that the same-sex marriage is legal though it has condecuted a wedding ceremony like an ordinary marriage,. In fact, the wedding ceremonu cam be undertaken due to one of the party falsify his/her identity, that is the party who uses male identity which actually biologically is a female The falsification of identity does not seem last long, as a woman as a normal wife definitely will suspicious when when a husband always refuse when asking to conduct a sexual intercourse. The people in the community in fact will be stormy when the fake identity of the husband is revealed. The legal consequences of the husband which falsify the identity is set tobe a suspect.

In the persepective of state law and customary law, same-sex marriage can not be legalized as it against the nature, means that the marriage has a holy goal to form a happy and eternal family based on the Almighty God. This goal can only be undertaken by a male and a female to have a baby as their. So people can develop only through marriage institution. Meanwhile the freedom which is embraced by the LGBT people is against with the meaning of freedom in Act of Human Right, the Act of marriage and Customary Law in Customary Villages in Bali, because the meaning of freedom which is said is in determining a mate as husband and wife which is free from intervence of any party. So the freedom as human right which is conducted in accordance withj the basic obligation to obey to any state regulations and customary law of the society as original law of Indonesia. This is the justice which give the benefits to most of of the society, that is in accordance with the culture of People in Indonesia that guarantees common order.

\section{Conclusion and Recommendation}

Same-Sex marriage is an international issue and in several coutries such as Dutch, Belgium, and Spain had legalized the existence in accordace to their own culture, but in Indonesia same-sex marriage is not accepted its existence in the law and human right perspective, means that the same-sex marriage can not be legalized, because the marriage can be undertaken by a man and a woman in accordance to religion law and believes and also recorded in accordance to the provisions of the regulations From the legal assurance aspect, there is no contradiction or duplication between the Act No. 1 year 1974 om Marriage with the Act No. 39 year 1999 on Human Right, thus also with the customary law as the reflection of the culture like Awig-Awig (traditional law) in Bali.

Considering this condition, it can be recommended that it is not necessary conducted antinomy between same-sex marriage with human right in Indonesia, because in understanding the regulations canm is not undertaken partially and piece by piece. Thus also it is not necessary to conduct an attempt to bang between Marriage Act with Human Right Act. And in interpreting freedom as Basic Right can not disown with the basic obligation. So the same-sex marriage should be analysed comprehensively from several different science, norm, and concept to be able to become foundation for the state in maintaining the legal assurance of the regulations which have been formed by the state through its tools.

\section{Regulations}

Burgerlijk Wetboek, 1961, Trans. R. Soebekti and Tjitrosudibio, Civil Code, Pradnya Paramita, Jakarta.

Act No. 1 Year 1974 on Marriage Gazetted of Republic of Indonesia, Year 1974 No 1. 
Act No. 39 Year 1999 on Human Right Gazetted of Republic of Indonesia Year1999 No 165.

Government Regulation No. 9 Year 1975 on the Implementation of Act No 1 Year 1974 on marriage, Gazetted of Republic of Indonesia Year 1975 No 12.

Customary Law of Gelgel Customary Village, 1980, Klungkung Sub-District, Klungkung Regency, Bali.

Customry Law of Sidakarya Customary Village, 1989, South of Denpasar Sub-District, Denpasar, Bali.

\section{References}

[1] Surojo Wignjodipuro, 1979, Introduction and Common Law Pricipals, Third Edition, Alumni, Bandung.

[2] Roescoe Pound, 1982, Introduction Philosophy of Law, Translate. Mohamad Rajab. Cetakan Ketiga. Bhratara Karya Aksara. Jakarta.

[3] Nyoman Nurjaya. 2006. Natural Resource Management in Anthropology Perspective of Law, First Edition. Cooperation of Master Program of Legal Science Graduate Program of Unibraw, ARENA LAW Magazine Faculty of Law Brawijaya Universitas with Publisher Malang Malang (UM PRESS Malang).

[4] Ronny Hanitijo Soemitro. 1983. Metodology of Legal Reseach. First Edition. Ghalia Indonesia. Jakarta.

[5] Peter Mahmud Marzuki, 2005. Legal Reseach. First Edition. Fajar Interpratama. Surabaya.

[6] Johnny Ibrahim. 2006. Theory \& Metodology of Normative Legal Reseach. Revition Edition. Second. Bayumedia Publishing, East Java.
[7] Jazim Hamidi. 2005. Hermeneutics of Law, The Theory of New Law Discovery by Text Interpretation, First Edition, UII Press, Yogyakarta.

[8] Earl Babbie. 1999. The Basics of Social Research. Wadsworth Publishing Company. Amerika.

[9] Edmund M.A. Kwaw. 1992. The Guide to Analisys, Legal Methodology and Legal Writing. Emond Montgomery Publications Limited. Canada.

[10] Wirjono Projodikoro, 1984, The Law of Marriage in Indonesia, Eighth Edition, Sumur Bandung, Jakarta.

[11] Subekti, 1982, The Principles of Civil law, Edition XVI, Intermasa Publisher, Jakarta.

[12] R.Soetojo Prawirohamidjojo and Asis afioedin, 1986, People Law and Family Law, Editon V, Alumni, Bandung.

[13] E. Utrecht, 1959, The Introduction to Indonesian Law, Sixth Edition, Penerbitan and Balai Buku "Ichtiar", Djakarta.

[14] E. Fernando M. Manullang, 2007, Reaching Justice Law, Buku Kompas Publisher, Jakarta.

[15] Michiel Otto, 2003, Reele rechtszakerheid in ontewikkellingslanden, trans. Trsitam Moeliono. Real Legal Certainty in Developing Countries, National Law Commission of the Republic of Indonesia (KHN-RI), First Editio.

[16] Darji Darmodiharjo dan Shidarta. 1996. Principles of Law Philosophy, what and how Law Pholosophy in Indonesia. Revision Edition. Second Edition. PT. Gramedia Pustaka Utama. Jakarta.

[17] Soleman B. Taneko 1987. Customary Law as First Introduction and Future Prediction. Eresco, Bandung. 